Chetan Sudhakar Sonawane

KMC College, Khopoli, Raigad,

Maharashtra, India

chetan.s2005@gmail.com
Прегледни рад

UDK 027.5:004.738.5(540)"2020"

616.98:578.834(100)"2020"

https://doi.org/10.18485/bibliotekar.2020.62.2.1

\title{
THE USE OF INTERNET TOOLS BY INDIAN LIS PROFESSIONALS FOR PROVIDING SUPPORT SERVICES DURING THE COVID-19 PANDEMIC
}

\begin{abstract}
This paper attempts to explore the use of internet by LIS professionals of India for providing library support services during the crisis of COVID-19. For this purpose, an online questionnaire was designed using Google forms and sent to Indian Listserv - ILOSC, NMLIS, LIS-Forum, and SALIS. The study finds that the majority of the LIS (Library and Information Science) professionals are providing library support services during the crisis of COVID-19 pandemic. The study also finds that LIS professionals were using all sorts of internet based communication tools even before the onset of COVID-19 pandemic. This seems to have helped the Indian LIS professionals in delivering services to the users. The study emphasizes further development and improvement of internet based communication tools for handling similar crises arising in the future.
\end{abstract}

Keywords: LIS professionals, internet, COVID-19, India.

\section{Introduction}

Coronavirus, also known as COVID-19, first case appeared in Wuhan, Hubei Province of China on $31^{\text {st }}$ December, 2019. The COVID-19 pandemic rapidly spread all over the world in a short span of time. As a result, most of the affected countries undergone lockdown during this period. India also has undergone lockdown in four phases - phase 1 ( $25^{\text {th }}$ March $-14^{\text {th }}$ April), phase 2 ( $15^{\text {th }}$ April $-3^{\text {rd }}$ May), phase 3 ( $4^{\text {th }}-17^{\text {th }}$ May), and phase $4\left(18^{\text {th }}-31^{\text {st }}\right.$ May). As 
a result, several schools, colleges, and universities had undergone a shutdown. ${ }^{1}$ The coronavirus spreads when an infected person comes in contact with persons who are not infected and the disease spreads when an infected person coughs or sneezes and the droplets are inhaled by persons who are not infected. The disease also spreads when persons who are not infected touch the affected area and later on touch their eyes, mouth, or nose. COVID-19 also affected all types of libraries the world over. Libraries the world over started initiatives to provide remote library services to their users. Libraries used several media to reach out to users, includinge mail, social networks, WhatsApp, website, video conferencing, online chat services, and others. Internet is a medium for communication with the users. Libraries provide several access points through which the library resources can be accessed, like WebOPAC, access to e-resources, research support services, etc. There is a need to draw a digital strategy, which should not be limited to access to e-resources only. A digital strategy should be formulated for transformation of the libraries, with an innovative vision for the service. To develop new digital strategy for libraries, libraries need to answer critically some questions like: how the libraries responded to online access of e-resources during COVID period; have libraries lost some users and connected with new users if any; has the perception of library vision changed in the collective imagination and if yes how $?^{2}$

\section{Literature review}

Tammaro in her paper describes the situation with COVID-19 and the role the Italian libraries played. ${ }^{3}$ The author has carried out the investigation by analyzing literature and online documents together with sending questionnaire to about 70 librarians. The author presents how the Italian libraries continued to offer services during COVID-19 pandemic lockdown by offering services like access to digital resources and reference services. The paper describes the use

\footnotetext{
Abubakar Ladan, Bala Haruna, and Augustine Uzoma Madu, "COVID-19 Pandemic and Social Media News in Nigeria: The Role of Libraries and Library Associations in Information Dissemination", International Journal of Innovation and Research in Educational Sciences 7, no. 2 (2020): 125-133.

2 Anna Maria Tammaro, "COVID 19 and Libraries in Italy", International Information \& Library Review (2020): 1-5.

3 Tammaro, “COVID 19... “: 1-5.
} 
of online communication tools like phone for video conference, social media for providing library services, etc.

Laden, Haruna and Madu in their paper talk about COVID-19 pandemic situation in Nigeria. ${ }^{4}$ The authors point to the role of libraries and library associations in information dissemination. The authors mention the issue of fake news in Nigeria. The authors also point to the role that various types of libraries like academic libraries and special libraries, as well as public libraries and library associations have in dissemination of information during COVID-19 pandemicus ing social media. The authors also mention certain challenges they face in Nigeria related to COVID-19.

Ifijeh and Yusuf in their paper talk about the role of academic libraries in the paradigm shift in teaching methodologies at Nigeria's universities due to the outbreak of COVID-19 pandemic. ${ }^{5}$ The authors point to the global trend in online education and the role of libraries. The authors mention post COVID-19 situation and the implications for Nigeria's university libraries which include responsive library website design, the adoption of the blended librarianship model, and the use of social networks. The paper also present the challenges involved in ICT (Information and Communication Technology) project implementation in Nigeria which includes apathy towards libraries and librarians, inadequate funding, poor technological infrastructure, the lack of skilled staff, etc.

\section{Objectives}

The objectives of the study are as follows:

To find out which internet based communication tools were used by LIS professionals prior to COVID-19 pandemic.

To find out which kind of library support services are provided by LIS professionals to their users.

To find out which types of tools are used by LIS professionals in providing library support services during COVID-19 pandemic.

Ladan, Haruna, and Uzoma Madu, “COVID-19 Pandemic...”, 125-133.

Goodluck Ifijeh, and Felicia Yusuf, "Covid-19 pandemic and the future of Nigeria's university system: The quest for libraries' relevance”, The Journal of Academic Librarianship 46, no. 6 (2020): 102226. 


\section{Methodology}

An online questionnaire was designed using Google forms it was sent to Indian Listserv - ILOSC, NMLIS, LIS-Forum, and SALIS. The questionnaire was made available for noting responses from $18^{\text {th }}$ April 2020 to mid June 2020. A total of 64 responses were received. The questionnaire consists of 12 questions. The first two questions are Name and Email address, required just to express thanks to the respondents for participating in the survey. So, only 10 questions are considered fit for data analysis. The first 4 questions are about demographic details of respondents and the remaining 6 questions are about the study. The collected data is collated and analyzed in the following section.

\section{Data analysis}

The questionnaire consists of 10 questions relevant for the study. Four questions relating to the study allow multiple responses, and they are related to internet based communication tools used pre and post COVID-19 situation, subscribed e-resources of the library, and the type of library support services provided to users currently. Other options are also provided to record favorable response. Two questions relating to study are of closed-ended type and allow responses in either Yes or No. The responses received are tabulated in MS-Excel 2007 and analyzed in the following sections:

\section{Designation}

The responses were received from 9 different designation holding respondents. The maximum responses were received from college librarians 41 (64.1\%) followed by college assistant librarians 7 (10.9\%), college library assistants 5 (7.8\%), university library assistants 4 (6.3\%), university librarians 2 (3.1\%), university assistant librarians 2 (3.1\%), associates Sr II B 1 (1.6\%), school librarians $1(1.6 \%)$, and professors and heads of LIS dept. 1 (1.6\%). 
Table 1: Designation related responses

\begin{tabular}{|c|l|c|}
\hline Sr. No. & Designation & $\begin{array}{c}\text { Responses } \\
(\mathbf{n}=\mathbf{6 4})\end{array}$ \\
\hline 1 & College librarians & $41(64.1 \%)$ \\
\hline 2 & College assistant librarians & $7(10.9 \%)$ \\
\hline 3 & College library assistants & $5(7.8 \%)$ \\
\hline 4 & University library assistants & $4(6.3 \%)$ \\
\hline 5 & University librarians & $2(3.1 \%)$ \\
\hline 6 & University assistant librarians & $2(3.1 \%)$ \\
\hline 7 & Associates Sr II B & $1(1.6 \%)$ \\
\hline 8 & School librarians & $1(1.6 \%)$ \\
\hline 9 & Professors and LIS Heads & $1(1.6 \%)$ \\
\hline & Total & $64(100 \%)$ \\
\hline
\end{tabular}

\section{Highest educational qualification}

The responses were received from 6 different educational qualification holding respondents. The highest response was from MLIS 32 (50\%) followed by PhD 21 (32.8\%), MPhil 6 (9.4\%), MLIS with NET 3 (4.7\%), MLIS with SET 1 (1.6\%), and MLIS with NET and SET 1 (1.6\%). NET stands for National Eligibility Test and SET means State Eligibility Test. NET and SET are exams conducted by the central and state agencies, respectively, for librarians to become eligible for working in colleges and universities.

Table 2: Education related responses

\begin{tabular}{|c|l|c|}
\hline Sr. No. & Education & $\begin{array}{c}\text { Responses } \\
(\mathbf{n = 6 4})\end{array}$ \\
\hline 1 & MLIS & $32(50 \%)$ \\
\hline 2 & PhD & $21(32.8 \%)$ \\
\hline 3 & MPhil & $6(9.4 \%)$ \\
\hline 4 & MLIS with NET & $3(4.7 \%)$ \\
\hline 5 & MLIS with SET & $1(1.6 \%)$ \\
\hline 6 & MLIS with NET and SET & $1(1.6 \%)$ \\
\hline & Total & $64(100 \%)$ \\
\hline
\end{tabular}




\section{Age group}

The responses were received from four different age groups. The maximum responses were received from 31-40 age group - 26 (40.6\%), followed by 41-50 age group - 20 (31.3\%), 21-30 age group - 9 (14.1\%), and 51-60 age group - 9 (14.1\%) responses.

Table 3: Age group related responses

\begin{tabular}{|c|c|c|}
\hline Sr. No. & Age group & $\begin{array}{c}\text { Responses } \\
(\mathbf{n}=64)\end{array}$ \\
\hline 1 & $31-40$ & $26(40.6 \%)$ \\
\hline 2 & $41-50$ & $20(31.3 \%)$ \\
\hline 3 & $21-30$ & $9(14.1 \%)$ \\
\hline 4 & $51-60$ & $9(14.1 \%)$ \\
\hline & Total & $64(100 \%)$ \\
\hline
\end{tabular}

\section{Sex}

The responses were received from 38 males which account for $59.4 \%$ of total respondents, 25 female participants also responded which account for $39.1 \%$ of total responses received from, and 1 response was received from other gender respondent which is $1.6 \%$ of total responses.

Table 4: Sex related responses

\begin{tabular}{|c|c|c|}
\hline Sr. No. & Sex & $\begin{array}{c}\text { Responses } \\
(\mathbf{n = 6 4 )}\end{array}$ \\
\hline 1 & Male & $38(59.4 \%)$ \\
\hline 2 & Female & $25(39.1 \%)$ \\
\hline 3 & Other & $1(1.6 \%)$ \\
\hline & Total & $64(100 \%)$ \\
\hline
\end{tabular}

\section{Library support services provided during the COVID-19crisis}

The question "Are you providing any library support services to your users during the current crisis of COVID-19 pandemic?" was asked. The responses received are shown below. There were $58(90.6 \%)$ respondents providing library support services during pandemic of COVID-19 and 6 (9.4\%) not providing them. 
Table 5: Library Support Services

\begin{tabular}{|c|c|c|}
\hline Sr. No. & $\begin{array}{c}\text { Library support } \\
\text { services provided }\end{array}$ & $\begin{array}{c}\text { Responses } \\
(\mathbf{n}=\mathbf{6 4})\end{array}$ \\
\hline 1 & Yes & $58(90.6 \%)$ \\
\hline 2 & No & $6(9.4 \%)$ \\
\hline & Total & $64(100 \%)$ \\
\hline
\end{tabular}

\section{Internet based communication tools used before COVID-19 crisis}

The question"Which of the internet based communication tools are used by you for your users in your library before COVID-19 pandemic?" was asked. The respondents were allowed to note multiple responses and 217 responses were received in total as indicated below. The question provided the first 7 responses as shown below to note along with other options to which there was one response. Email is the most widely used internet based communication tool - 52 (81.3\%),followed by WhatsApp - 47 (73.4\%), social networks - 35 (54.7\%), website - 30 (46.9\%), video conferencing - 25 (39.1\%), online chat service - 14 (21.9\%), electronic forum - 13 (20.3\%), and YouTube channel - 1 (1.6\%).

Table 6: Internet based communication tools used before COVID-19

\begin{tabular}{|c|l|c|}
\hline Sr. No. & $\begin{array}{l}\text { Internet based communication tool } \\
\text { used before COVID-19 crisis }\end{array}$ & $\begin{array}{c}\text { Responses } \\
(\mathbf{n = 6 4 )}\end{array}$ \\
\hline 1 & Email & $52(81.3 \%)$ \\
\hline 2 & Social networks & $35(54.7 \%)$ \\
\hline 3 & Website & $30(46.9 \%)$ \\
\hline 4 & WhatsApp & $47(73.4 \%)$ \\
\hline 5 & Electronic forum & $13(20.3 \%)$ \\
\hline 6 & Video conferencing & $25(39.1 \%)$ \\
\hline 7 & Online chat service & $14(21.9 \%)$ \\
\hline 8 & YouTube channel & $1(1.6 \%)$ \\
\hline
\end{tabular}

\section{Library support services provided to current users}

The question "What kind of library support service is provided by you to your current users?" was asked. The respondents were allowed to record multiple responses; the total responses received were 204 and as shown below. The 
question provided the first 7 responses to record along with other options which allowed recording of more responses. In total, there were 12 responses received. Compilation or sharing list of free e-resources is the kind of library support service provided to current users by most LIS professionals of India - 51 (79.7\%) followed by Sharing of list of open access e-resources - 48 (75\%), Sharing notices sent by UGC, AICTE and universities - 39 (60.9\%), Sharing of newspaper clippings - 27 (42.2\%), Conducting webinars - 21 (32.8\%), Sharing of reference management software presentation - 12 (18.8\%), surprisingly one participant responded None of the above (1.6\%) option. Other options which provided flexibility to respondent to note responses received with regard to library support services provided to current users were Remote access to subscribed e-resources - 1 (1.6\%), Access to question papers provided - 1 (1.6\%), Provided information about medical webinar on COVID-19-1 (1.6\%), Literature searching help provided - 1 (1.6\%), and Sharing of self made videos and other government initiatives - 1 (1.6\%).

Table 7: Library Support Service provided to current users

\begin{tabular}{|c|l|c|}
\hline Sr. No. & Library support service provided & $\begin{array}{c}\text { Response received } \\
(\mathbf{n = 6 4})\end{array}$ \\
\hline 1 & $\begin{array}{l}\text { Compilation or sharing list of free } \\
\text { e-resources }\end{array}$ & $51(79.7 \%)$ \\
\hline 2 & $\begin{array}{l}\text { Sharing of list of open access } \\
\text { e-resources }\end{array}$ & $48(75 \%)$ \\
\hline 3 & $\begin{array}{l}\text { Sharing notices sent by UGC, AICTE } \\
\text { and Universities }\end{array}$ & $39(60.9 \%)$ \\
\hline 4 & Sharing of newspaper clippings & $27(42.2 \%)$ \\
\hline 5 & Conducting webinars & $21(32.8 \%)$ \\
\hline 6 & $\begin{array}{l}\text { Sharing of Reference Management } \\
\text { Software presentation }\end{array}$ & $12(18.8 \%)$ \\
\hline 7 & None of the above & $1(1.6 \%)$ \\
\hline 8 & Remote access to subscribed e-resources & $1(1.6 \%)$ \\
\hline 9 & Question papers & $1(1.6 \%)$ \\
\hline 10 & $\begin{array}{l}\text { Provide info about medical webinar on } \\
\text { COVID-19 }\end{array}$ & $1(1.6 \%)$ \\
\hline 11 & Literature searching & $1(1.6 \%)$ \\
\hline 12 & $\begin{array}{l}\text { Sharing of videos self made, other } \\
\text { government initiatives }\end{array}$ & $1(1.6 \%)$ \\
\hline
\end{tabular}

UGC - University Grant Commission, AICTE - All India Council for Technical Education 


\section{Tools currently used for providing library support services during COVID-19 pandemic}

The question "Which tools are you currently using for providing library support services during COVID-19 pandemic?" was asked. The respondents were allowed to choose multiple responses; a total of 176 responses were received as shown below. The question provided first 6 responses as shown below along with other option which allowed noting multiple responses. The question received 11 responses in total. As the responses indicated,email is the most widely used tool during COVID-19 pandemic for providing library support services - 57 (89.1\%), followed by WhatsApp - 50 (78.1\%), Zoom - 30 (46.9\%), Youtube - 17 (26.6\%), and Facebook - 15 (23.4\%). There were also $2(3.1 \%)$ responses None of the above. The other responses received are CMS - 1 (1.6\%), Google Classroom - $1(1.6 \%)$, Microsoft Teams - 1 (1.6\%), mobile phone for personal communication - 1 (1.6\%), Microsoft Teams and CISCO Webex - 1 (1.6\%).

Table 8: Tools currently used for providing library support services

\begin{tabular}{|c|l|c|}
\hline Sr. No. & $\begin{array}{l}\text { Tools currently used for providing } \\
\text { library support services during } \\
\text { COVID-19 pandemic }\end{array}$ & $\begin{array}{c}\text { Responses } \\
(\mathbf{n = 6 4 )}\end{array}$ \\
\hline 1 & Facebook & $15(23.4 \%)$ \\
\hline 2 & Youtube & $17(26.6 \%)$ \\
\hline 3 & Zoom & $30(46.9 \%)$ \\
\hline 4 & Email & $57(89.1 \%)$ \\
\hline 5 & WhatsApp & $50(78.1 \%)$ \\
\hline 6 & None of the above & $2(3.1 \%)$ \\
\hline 7 & CMS & $1(1.6 \%)$ \\
\hline 8 & Google Classroom & $1(1.6 \%)$ \\
\hline 9 & Microsoft Team & $1(1.6 \%)$ \\
\hline 10 & $\begin{array}{l}\text { Mobile phone for personal } \\
\text { communication }\end{array}$ & $1(1.6 \%)$ \\
\hline 11 & Microsoft Team, Cisco Webex & $1(1.6 \%)$ \\
\hline
\end{tabular}

CMS - Content Management System 


\section{Access to subscribed e-resources provided}

The question "Which type of subscribed e-resources access is provided by your library remotely?" was asked. The question provided only 2 responses to record along with other option which allowed noting multiple responses and a total of 6 responses were received. A total of 105 responses were received. Access to e-journals database is provided by maximum respondents i.e. 56 (87.5\%) followed by $44(68.8 \%)$, then N-List database $-2(3.12 \%)$ that is a database provided to college libraries under INFLIBNET N-List consortia in India, newspapers - 1 (1.6\%), old thesis softcopy for reference only - $1(1.6 \%)$, and index and statistical database - 1 (1.6\%).

Table 9: Access to subscribed e-resources provided

\begin{tabular}{|c|l|c|}
\hline Sr. No. & $\begin{array}{l}\text { Access to subscribed } \\
\text { e-resources provided }\end{array}$ & $\begin{array}{c}\text { Response received } \\
(\mathbf{n = 6 4 )}\end{array}$ \\
\hline 1 & E-books & $44(68.8 \%)$ \\
\hline 2 & E-journals database & $56(87.5 \%)$ \\
\hline 3 & N-List database & $2(3.12 \%)$ \\
\hline 4 & Newspapers & $1(1.6 \%)$ \\
\hline 5 & Old thesis softcopy for reference only & $1(1.6 \%)$ \\
\hline 6 & Index and statistical database & $1(1.6 \%)$ \\
\hline
\end{tabular}

\subsection{Research support service provided}

The question "Does your library provide any kind of research support service currently?" was asked. The question was close ended. The responses received are shown below. The respondents providing research support services during the pandemic of COVID-19 were $43(67.2 \%)$ and those not providing were $21(32.8 \%)$.

Table 10: Research support service provided

\begin{tabular}{|c|l|c|}
\hline Sr. No. & Research support services provided & $\begin{array}{c}\text { Responses } \\
(\mathbf{n}=\mathbf{6 4})\end{array}$ \\
\hline 1 & Yes & $43(67.2 \%)$ \\
\hline 2 & No & $21(32.8 \%)$ \\
\hline & Total & $64(100 \%)$ \\
\hline
\end{tabular}




\section{Findings of the study}

The study highlights some important findings related to the internet tools used by LIS professionals in India before and during COVID-19 situation. The study also acknowledges the kind of library support services provided by LIS professionals in India. The findings are mentioned below:

Email and WhatsApp are the most used tools by LIS professionals before and during COVID-19 situation.

Social networks like Facebook and YouTube are used before and during COVID-19 situation equally.

The access to subscribed e-resources like e-journals database and e-books database is provided.

\section{Conclusion}

The study finds that LIS (Library and Information Science) professionals of India have been well equipped to provide library support services during the lockdown using various internet based communication tools. Because the LIS professionals have been connected with their users, it seems to have helped them to provide library support services. Emails and WhatsApp are the most used tools before and during COVID-19 situation, followed by websites and social networks respectively. This may be due to easy accessibility of social networks like Facebook and YouTube. Remote access to subscribed e-resources like e-journals and e-books are provided. Library support services and research support services are also provided by most LIS professionals. Tools for conducting meetings and webinars are highly used by LIS professionals. Tools like Zoom, Cisco Webex, and Microsoft Teams are highly used, which was not the case earlier. 


\section{References:}

1. Ifijeh, Goodluck, and Felicia Yusuf. "Covid-19 pandemic and the future of Nigeria's university system: The quest for libraries' relevance." The Journal of Academic Librarianship 46, no. 6 (2020): 102226.

2. Ladan, Abubakar, Bala Haruna, and Augustine Uzoma Madu. "COVID-19 Pandemic and Social Media News in Nigeria: The Role of Libraries and Library Associations in Information Dissemination." International Journal of Innovation and Research in Educational Sciences 7, no. 2 (2020): 125-133.

3. Tammaro, Anna Maria. "COVID 19 and Libraries in Italy." International Information \& Library Review (2020): 1-5.

\section{Четан Судакар Сонаване}

КМЦ колеџ, Кополи, Рајгад, Махараштра, Индија

chetan.s2005@gmail.com

\section{КОРИШЋЕЊЕ ИНТЕРНЕТ АЛАТА ЗА ПРУЖАЊЕ БИБЛИОТЕЧКИХ УСЛУГА ТОКОМ ПАНДЕМИЈЕ КОВИД-19 У БИБЛИОТЕКАМА ИНДИЈЕ}

Сажетак: Овај рад покушава да истражи коришћење интернета приликом пружања услуга у библиотекама у Индији током кризе узроковане заразном болешћу ковид-19. У ту сврху направљен је онлајн упитник помоћу Гугл образаца и послат на имејлинг листе библиотекара у Индији. Студија открива да је већина библиотекара пружала библиотечке услуге током пандемије ковида-19, али и да су библиотекари користили различите интернет алате за комуникацију чак и пре почетка пандемије. То је умногоме помогло индијским библиотекарима у пружању услуга корисницима. Студија наглашава даљи развој и усавршавање комуникационих алата на интернету за суочавање са потенцијалним сличним кризама у будућности.

Кључне речи: библиотекари, интернет, ковид-19, Индија.

Примљено: 1. септембра 2020.

Исправке: 8. октобра 2020. Прихваћено: 27. октобра 2020. 